\title{
Het nemo-teneturbeginsel in de conceptwetsvoorstellen van het Wetboek van Strafvordering
}

Citation for published version (APA):

van Toor, D. A. G. (2018). Het nemo-teneturbeginsel in de conceptwetsvoorstellen van het Wetboek van Strafvordering. Tijdschrift voor Bijzonder Strafrecht \& Handhaving, 2018(4), 249-254.

https://doi.org/10.5553/TBSenH/229567002018004004005

DOI:

10.5553/TBSenH/229567002018004004005

Document status and date:

Published: 01/01/2018

Document Version:

Publisher's PDF, also known as Version of record

Document license:

CC BY-NC-ND

Please check the document version of this publication:

- A submitted manuscript is the version of the article upon submission and before peer-review. There can be important differences between the submitted version and the official published version of record. People interested in the research are advised to contact the author for the final version of the publication, or visit the DOI to the publisher's website.

- The final author version and the galley proof are versions of the publication after peer review.

- The final published version features the final layout of the paper including the volume, issue and page numbers.

Link to publication

\section{General rights}

Copyright and moral rights for the publications made accessible in the public portal are retained by the authors and/or other copyright owners and it is a condition of accessing publications that users recognise and abide by the legal requirements associated with these rights.

- Users may download and print one copy of any publication from the public portal for the purpose of private study or research.

- You may not further distribute the material or use it for any profit-making activity or commercial gain

- You may freely distribute the URL identifying the publication in the public portal.

If the publication is distributed under the terms of Article 25fa of the Dutch Copyright Act, indicated by the "Taverne" license above, please follow below link for the End User Agreement:

https://www.ou.nl/taverne-agreement

Take down policy

If you believe that this document breaches copyright please contact us at:

pure-support@ou.nl

providing details and we will investigate your claim.

Downloaded from https://research.ou.nl/ on date: 26 Apr. 2023 


\title{
Artikel
}

\section{Het nemo-teneturbeginsel in de conceptwetsvoorstellen van het Wetboek van Strafvordering}

\author{
D.A.G. van Toor PhD LLM BSc*
}

\section{Inleiding}

Het nemo-teneturbeginsel vormt een belangrijke begrenzing van overheidsmacht tijdens de bewijsgaring in strafzaken. In het algemeen wordt onder het nemoteneturbeginsel verstaan dat de verdachte niet kan worden gedwongen aan zijn eigen veroordeling mee te werken. Het beginsel heeft echter geen algemene gelding: de verdachte kan niet verhinderen dat de justitiële autoriteiten dwangmiddelen en opsporingsbevoegdheden tegen hem inzetten, ook methoden die hij ten minste passief moet dulden. Zo moet hij bijvoorbeeld dulden dat in zijn huis naar in beslag te nemen goederen wordt gezocht of dat lichaamsmateriaal voor een DNA-analyse van hem wordt afgenomen.

Veelal blijft wel onduidelijk waar de grens tussen geoorloofde en ongeoorloofde 'medewerking' aan de eigen

\footnotetext{
D.A.G. (Dave) van Toor PhD LLM BSc is verbonden als universitair docent aan de Open Universiteit en als wetenschappelijk medewerker Straf(proces)recht \& Criminologie aan de Universität Bielefeld (Duitsland). Hij schreef meerdere artikelen over de verplichting tot meewerken aan de uitvoering van een opsporingsbevoegdheid, zoals het decryptiebevel, de ontgrendeling van een smartphone en administratieen inlichtingenverplichtingen. Deze bijdrage borduurt voort op zijn algemene visie omtrent het nemo-teneturbeginsel, die uitvoering uiteen is gezet in: D.A.G. van Toor, Het schuldige geheugen? Een onderzoek naar het gebruik van hersenonderzoek als opsporingsmethode in het licht van eisen van instrumentaliteit en rechtsbescherming (diss. Nijmegen), Deventer: Kluwer 2017, p. 369-431; D.A.G. van Toor, 'Het nemo-teneturbeginsel: rechtspraak van het Europese Hof voor de Rechten van de Mens en de Hoge Raad vergeleken', TBS\&H 2016, 1, p. 28-43.
}

veroordeling ligt. Dit maakt dat de introductie van nieuwe opsporingsbevoegdheden door de wetgever in de rechtswetenschappelijke literatuur regelmatig aan het nemo-teneturbeginsel wordt getoetst. ${ }^{1}$ In de modernisering van het Wetboek van Strafvordering gaat deze discussie verder: de wetgever heeft in het conceptwetsvoorstel Boek 2 verplichtingen voor de verdachte opgenomen om mee te werken aan een handschriftanalyse of een stemvergelijking, twee verplichtingen die het huidige wetboek niet kent. In deze bijdrage wordt de vraag beantwoord of de nieuwe opsporingsmethoden, waarbij de verdachte een actieve handeling moet verrichten, het nemo-teneturbeginsel schenden.

De bespreking van deze bevoegdheden uit de modernisering van het Wetboek van Strafvordering in het licht van het nemo-teneturbeginsel vindt hieronder in twee stappen plaats. Ten eerste wordt uit de memories van toelichting de visie van de wetgever omtrent het nemoteneturbeginsel gedistilleerd en met de rechtspraak van het EHRM vergeleken (par. 2). Vervolgens behandelt paragraaf 3 de nieuwe opsporingshandelingen waaraan de verdachte mee moet werken. Zoals hierboven al genoemd, zijn dat het meewerken aan een stem- of handschriftvergelijking waarbij de verdachte een actieve handeling (spreken of schrijven) moet verrichten. Para-

1. Zie D. van Toor, 'Het decryptiebevel en het nemo-teneturbeginsel', NJB 2013, 8, p. 477-479; D.A.G. van Toor, 'Over het nemo-teneturbeginsel en het decryptiebevel: is een meewerkverplichting bij het ontsleutelen van bestanden gerechtvaardigd?', Strafblad 2013, 4, p. 317-323; E.M van Gelder \& D.A.G. van Toor, 'Het nemo-teneturbeginsel en de verhouding met de Wet Herziening strafbaarstelling faillissementsfraude', TBS\&H 2016, 3, p. 161-168; D.A.G. van Toor, 'De vergrendelde smartphone als object van strafvorderlijk onderzoek', Computerrecht 2017, 1, p. 3-11; E.J. Gritter, 'Het decryptiebevel aan de verdachte in het economisch strafrecht', TBS\&H 2017, 4, p. 190-192. 
graaf 4 rondt deze bijdrage af. Mijn conclusies zijn dat (i) de visie die wetgever over het nemo-teneturbeginsel uiteenzet niet strookt met de rechtspraak van het EHRM en; (ii) dat de verplichting actief mee te werken aan een stem- en handschriftvergelijking het nemo-teneturbeginsel schendt (en daarnaast dat de vergelijking betrouwbaarder kan worden uitgevoerd zonder onder dwang afgenomen materiaal).

\section{De wetgever over het nemo- teneturbeginsel}

Om te beoordelen waarom de wetgever heeft besloten de onderhavige opsporingsmethoden te introduceren, wordt eerst de visie die de wetgever uiteenzet in de conceptmemories van toelichting besproken. De wetgever merkt daarin het volgende over het nemo-teneturbeginsel op: '[H] et nemo-teneturbeginsel [ligt] in artikel 6 EVRM besloten. Dit beginsel wordt algemeen opgevat als het beginsel dat verdachten niet aan hun eigen veroordeling hoeven mee te werken. [..] Het beginsel wordt vaak in één adem met het zwijgrecht genoemd: "the privilege against self-incrimination is commonly understood [...] to be [i]primarily concerned with respecting the will of the defendant to remain silent in the face of questioning and not to be compelled to provide a statement", aldus het EHRM (vgl. EHRM 11 juli 2006, Jalloh v. Duitsland, § 110). [ii] Wat niet door het nemo-teneturbeginsel beschermd wordt, is materiaal dat onafhankelijk van de wil van de verdachte bestaat. In de zaak Saunders tegen het Verenigd Koninkrijk oordeelde het EHRM namelijk dat het recht om zichzelf niet te hoeven belasten, zich niet uitstrekt tot bewijsmateriaal dat onder dwang in een strafrechtelijke procedure is verkregen, maar onafhankelijk van de wil van de verdachte bestaat. [...] Deze beperking van het recht om zichzelf niet te hoeven belasten, valt goed te begrijpen in het licht van een [iii] belangrijke, door het Hof genoemde functie van dit recht: het voorkomen van rechterlijke dwalingen als gevolg van ongepaste druk op de verdachte. Onder dwang verkregen mondelinge verklaringen kunnen tot rechterlijke dwalingen leiden. Dat geldt niet voor wilsonafhankelijk bewijsmateriaal omdat dat niet verandert al naar gelang dat vrijwillig of onder dwang wordt afgestaan (mijn onderstreping en nummering). ${ }^{2}$ Deze lezing van de EHRM-jurisprudentie over het nemo-teneturbeginsel is selectief en foutief. Deze twee punten worden hieronder nader uitgewerkt.

\subsection{Selectieve weergave van de functies van het nemo-teneturbeginsel}

De wetgevers visie is ten eerste selectief. De wetgever richt zich namelijk eenzijdig op een van de door het EHRM nevengestelde doelen van het nemo-teneturbeginsel, terwijl het andere doel volledig onbesproken

2. Memorie van toelichting: Vaststellingswet Boek 2 van het nieuwe Wetboek van Strafvordering (Het opsporingsonderzoek), p. 73-74. blijft (derde onderstreping in het citaat hierboven). De rechtsoverweging waarop de wetgever zich beroept, luidt als volgt: 'Their (het zwijgrecht en het nemo-teneturbeginsel) rationale lies, inter alia, in the protection of the accused against improper compulsion by the authorities thereby contributing to the avoidance of miscarriages of justice and to the fulfilment of the aims of Article $6[\ldots]$. The right not to incriminate oneself, in particular, presupposes that the prosecution in a criminal case seek to prove their case against the accused without resort to evidence obtained through methods of coercion or oppression in defiance of the will of the accused.' 3

Het EHRM benadrukt dat het nemo-teneturbeginsel en het zwijgrecht onder andere eraan bijdragen dat (1) geen ongeoorloofde dmang op de verdachte wordt toegepast zodat (2) rechterlijke dmalingen worden voorkomen en (3) de doelen van artikel 6 EVRM worden vervuld. Met betrekking tot het vervullen van de doelen van artikel 6 EVRM gaat het vooral om het respecteren van de wil van de verdachte ${ }^{4}$ waardoor een tegensprekelijk proces wordt gewaarborgd/mogelijk wordt gemaakt. De tweede functie van het nemo-teneturbeginsel en het zwijgrecht - dat zij bijdragen aan het respecteren van de wil van de verdachte, namelijk doordat hij niet wordt gedwongen bewijs tegen zichzelf te leveren maar zelfstandig kan bepalen welke bewijsmiddelen hij inbrengt en welk verhaal hij vertelt ${ }^{5}$ - wordt door de wetgever over het hoofd gezien.

Het nemo-teneturbeginsel heeft dus niet alleen als doel het voorkomen van rechterlijke dwalingen, maar ook dat de verdachte als procespartij zijn eigen proceshouding kan bepalen. Als de betrouwbaarheid van het bewijs het enige doel van het nemo-teneturbeginsel zou zijn, betekent dit in de meest vergaande variant dat elke opsporingshandeling geoorloofd is die betrouwbaar bewijs oplevert, ongeacht de dwang die op de verdachte wordt toegepast. Zoals de wetgever correct beschrijft, tast dwang alleen de betrouwbaarheid van afhankelijk van de wil bestaand materiaal aan. In die zin heeft de wetgever dus gelijk dat het voorkomen van rechterlijke dwalingen voor het nemo-tenturbeginsel betekent dat de opsporingsambtenaren geen onbetrouwbaar bewijs produceren door de verdachte te dwingen (te spreken). Maar dat is niet het enige doel van het nemo-teneturbeginsel. Het andere doel - het respecteren van de wil van de verdachte - staat bij elke vorm van dwang, ongeacht welk soort bewijsmiddel daarmee wordt verkregen,

3. EHRM 17 december 1992, ECLI:CE:ECHR:1996:1217JUD001918791, par. 68 (Saunders t. het Verenigd Koninkrijk).

4. EHRM 5 november 2002, ECLI:CE:ECHR:2002:1105JUD004853999, par. 44 (Allan t. het Verenigd Koninkrijk); EHRM (GK) 10 maart 2009 ECLI:CE:ECHR:2009:0310JUD000437802 par. 92 (Bykov t. Rusland); EHRM 1 februari 2011, ECLI:CE:ECHR:2011:0201JUD002390903, par. 127 (Desde t. Turkije); EHRM (GK) 28 november 2013, ECLI:CE:ECHR: 2015:1020JUD002570311, par. 91 (Dvorski t. Kroatië).

5. Zie daarover uitgebreid D.A.G. van Toor, Het schuldige geheugen? Een onderzoek naar het gebruik van hersenonderzoek als opsporingsmethode in het licht van eisen van instrumentaliteit en rechtsbescherming (diss. Nijmegen), Deventer: Kluwer 2017, p. 379-384. Zie ook G.J.M. Corstens \& M.J. Borgers, Het Nederlandse strafprocesrecht, Deventer: Kluwer 2014, p. 306. 
onder druk. Door dit tweede doel te negeren, presenteert de wetgever een eenzijdige, selectieve visie op het nemo-teneturbeginsel. Een visie die niet strookt met de jurisprudentie van het EHRM over de autonome positie van een verdachte in eerlijk proces.

\subsection{Foutieve interpretatie van de jurisprudentie omtrent het nemo-teneturbeginsel}

Daarnaast is de interpretatie van de wetgever van de EHRM-jurisprudentie over het nemo-teneturbeginsel gedeeltelijk onjuist. De wetgever vereenzelvigt het nemo-teneturbeginsel met het zwijgrecht (zie het aan het begin van deze paragraaf opgenomen citaat). Dit is niet volkomen onlogisch - het EHRM noemt beide eerlijk-procesrechtonderdelen vaak in een adem -, maar theoretisch zijn zij niet hetzelfde. De bescherming van het zwijgrecht en het nemo-teneturbeginsel overlappen slechts gedeeltelijk, en hebben daarnaast ook een eigen, uniek beschermingsbereik. Dit kan ook al worden afgeleid uit het woord primarily (zoals dat is opgenomen in het citaat bij de eerste onderstreping). Het nemo-teneturbeginsel is primair van belang om verdachte's zwijgen te respecteren. Het woord primair maakt direct duidelijk dat dit niet het enige bereik is waar de verdachte tegen overheidsdwang wordt beschermd. Het zwijgrecht bepaalt namelijk dat de verdachte in een strafproces te allen tijde mag zwijgen. De bescherming is derhalve heel breed - altijd - en heel smal - het betreft alleen verklaringen. Op het eerste gezicht ligt op dat laatste gebied, ter aanvulling van de enge bescherming van bepaalde bewijsmiddelen, ruimte voor het nemo-teneturbeginsel. Volgens mij is dat ook de ruimte die het nemo-teneturbeginsel hoort in te nemen. Hiervoor is het onderscheid tussen een means based nemo-tenturbeginsel en een material based nemo-teneturbeginsel van belang. ${ }^{6}$

Het means based nemo-teneturbeginsel beschermt de verdachte tegen ongeoorloofde middelen om bewijs te vergaren. Het material based nemo-teneturbeginsel beschermt de verdachte tegen gedwongen verkrijging van materiaal dat afhankelijk van zijn mil bestaat. Mijns inziens kan de laatste variant van het beginsel vanwege twee redenen niet de bedoelde werking van het nemoteneturbeginsel zijn.

Ten eerste leidt een material based nemo-teneturbeginsel tot exact (of voor een zeer groot deel) dezelfde bescherming als het zwijgrecht. Dit is theoretisch onlogisch. Uit de beschrijving van het beginsel - nemo tenetur se ipsum prodere, letterlijk: niemand is verplicht tegen zichzelf te produceren - volgt ook dat het niet alleen gaat over verbale uitlatingen. Ondanks dat het zwijgrecht en het nemo-teneturbeginsel vaak in een adem worden genoemd, is algemeen aanvaard dat beide internationale

6. Dit verschil is ontleed aan $M$. Redmayne, 'Rethinking the Privilege Against Self-Incrimination', Oxford Journal of Legal Studies 2007, 2, p. 215 , en wordt uitgebreid besproken in mijn proefschrift (o.a. op p. 394 e.v., 426 e.v.). Deze paragraaf is grotendeels daarop gebaseerd. Zie ook E.J. Gritter, 'Het decryptiebevel aan de verdachte in het economisch strafrecht', TBS\&H 2017, 4, p. 190-192. standaarden voor een eerlijk proces zijn die naast elkaar bestaan. Theoretisch hebben zij een eigen beschermingsbereik: Het nemo-teneturbeginsel beschermt de verdachte tegen elke vorm van bewijsgaring onder dwang door de autoriteiten. Het zwijgrecht daarentegen geeft de verdachte enkel de mogelijkheid om niet te spreken. Daar staat tegenover dat het zwijgrecht een bredere bescherming biedt dan het nemo-teneturbeginsel met betrekking tot het moment dat het recht kan worden ingeroepen. Het zwijgrecht kan immers te allen tijde worden ingeroepen, ook als er geen dwang wordt gebruikt om een verklaring te verkrijgen. Het nemoteneturbeginsel daarentegen speelt pas een rol van betekenis als de autoriteiten de verdachte dwingen mee te werken.

Ten tweede zet een material based-beginsel de deur wagenwijd open voor onrechtmatige opsporing. Het nemo-teneturbeginsel beschermt dan namelijk alleen tegen de gedwongen verkrijging van een bepaald type bewijs. Enkel bij dit type bewijsmateriaal kan de verdachte de bescherming van het nemo-teneturbeginsel inroepen. Bij elke vorm van verkrijging onder dwang van alle andere soorten bewijsmiddelen beschermt het nemo-teneturbeginsel hem niet. Dit strookt niet met onder andere de rule of lam, de ideeën over een eerlijk proces en de mogelijkheid voor partijen (en dus ook de verdediging) om zelfstandig en autonoom beslissingen te nemen in het proces.

In de kern is het nemo-teneturbeginsel een beginsel dat de verdachte beschermt tegen ongeoorloofde gedwongen medewerking aan de bewijsgaring, onafhankelijk van het type bewijs. De EU ziet de bescherming van het nemo-teneturbeginsel op deze manier, en ook het EHRM benadrukt dat het nemo-teneturbeginsel de verdachte beschermt tegen het verkrijgen van bewijs door 'coercion or oppression'. ${ }^{7}$ Op deze wijze heeft het nemoteneturbeginsel bestaansrecht naast het zwijgrecht en biedt het nemo-teneturbeginsel bescherming tegen elke ongeoorloofde opsporingshandeling die de verdachte dwingt mee te werken/moet dulden. Het nemo-teneturbeginsel beschermt dus niet tegen de gedwongen verkrijging van bepaalde bewijsmiddelen, maar juist tegen ongeoorloofde vormen van bewijsvergaring.

De vereenzelviging van het zwijgrecht en het nemoteneturbeginsel door de wetgever zet zich voort bij de beschrijving van het concrete beschermingsbereik. Kort gezegd, ziet de wetgever de bescherming als volgt (zie ook de tweede onderstreping in het citaat aan het begin van deze paragraaf): (1) bewijs dat afhankelijk van de wil bestaat, valt onder de bescherming van het beginsel; (2)

7. Zie art. 7 lid 3 Richtlijn (EU) 2016/343: ‘De uitoefening van het recht om zichzelf niet te belasten mag de bevoegde autoriteiten niet beletten bewijsmateriaal te vergaren dat rechtmatig wordt verkregen door gebruik van legale dwang en dat onafhankelijk van de wil van de verdachten of beklaagden bestaat (mijn onderstreping)'; EHRM (GK) 13 september 2016, ECLI:CE:ECHR:2016:0913JUD005054108 (Ibrahim e.a. $t$. het Verenigd Koninkrijk), par. 267: 'It is important to recognise that the privilege against self-incrimination does not protect against the making of an incriminating statement per se but, as noted above, against the obtaining of evidence by coercion or oppression.' 
materiaal dat onafhankelijk van de wil bestaat, waarover een mens met enkel zijn wil of zijn gedachten geen controle heeft, valt niet onder de bescherming van het beginsel. Deze door de wetgever gebezigde interpretatie van Saunders is incorrect (omdat die zaak centraal wordt gesteld, en dat is mijns inziens een verkeerd perspectief). ${ }^{8}$

Ten eerste staat deze 'bescherming' niet op deze manier in de arresten van het EHRM. De rechtsoverweging waarnaar bij deze interpretatie wordt verwezen is nummer 69 uit het Saunders-arrest. ${ }^{9}$ Daarin wordt het volgende overwogen: 'the privilege against self-incrimination does not extend to the use in criminal proceedings of material which may be obtained from the accused through the use of compulsory powers but which has an existence independent of the will of the suspect such as, inter alia, documents acquired pursuant to a warrant, breath, blood, urine, hair or voice samples and bodily tissue for the purpose of DNA testing' (mijn onderstreping). Het onderstreepte gedeelte wordt bij de interpretatie van de wetgever over het hoofd gezien, terwijl het een essentieel deel van de rechtsoverweging is. Het EHRM overweegt namelijk dat materiaal dat onafhankelijk van de wil bestaat met gebruikmaking van rechtmatige dwang/de rechtmatige inzet van een dwangmiddel mag worden verkregen, en niet dat dat materiaal met elke vorm van dwang mag worden verkregen.

Ten tweede blijkt dit ook overduidelijk uit andere arresten van het EHRM (en daarom moet de focus niet op Saunders worden gelegd). In Falloh wordt het nemoteneturbeginsel geschonden omdat de drugs - die onafhankelijk van de wil bestaan - met onrechtmatige dwang worden verkregen. ${ }^{10}$ In onder andere Funke en $7 . B$. wordt het nemo-teneturbeginsel geschonden ondanks dat documenten - die onafhankelijk van de wil bestaan onder dwang worden verkregen. ${ }^{11}$ Het is overduidelijk dat ook de verkrijging van materiaal dat onafhankelijk van de wil bestaat het nemo-teneturbeginsel kan schenden. Het is dus niet de aard van het materiaal dat beslissend is bij de beoordeling of het nemo-teneturbeginsel is geschonden.

Ten derde heeft het EHRM eerst in Falloh en vervolgens in O'Halloran E Francis een drietal criteria benoemd waarmee een klacht over schending van het nemo-teneturbeginsel wordt beoordeeld. Dit zijn: (1) de mate en aard van dmang die werd gebruikt om het bewijs

8. Blijkbaar moet dit telkens opnieuw worden benadrukt. D.A.G. van Toor, ‘Het nemo-teneturbeginsel: rechtspraak van het Europese Hof voor de Rechten van de Mens en de Hoge Raad vergeleken', TBS\&H 2016, 1, p. 29-30; E.M. van Gelder \& D.A.G. van Toor, 'Het nemo-teneturbeginsel en de verhouding met de Wet Herziening strafbaarstelling faillissementsfraude', TBS\&H 2016, 3, p. 165; D.A.G. van Toor, 'Over het nemo-teneturbeginsel en het decryptiebevel: is een meewerkverplichting bij het ontsleutelen van bestanden gerechtvaardigd?', Strafblad 2013, 4, p. 318.

9. EHRM 17 december 1992, ECLI:CE:ECHR:1996:1217JUD001918791, par. 68 (Saunders t. het Verenigd Koninkrijk)

10. EHRM (GK) 11 juli 2006, ECLI:CE:ECHR:2006:0711JUD005481000 (Jalloh t. Duitsland)

11. EHRM 25 februari 1993, ECLI:CE:ECHR:1993:0225JUD001082884 (Funke t. Frankrijk); EHRM 3 mei 2001, ECLI:CE:ECHR: 2001:0503JUD003182796 (J.B. t. Zwitserland). te verkrijgen; (2) relevante paarborgen in de procedure en; (3) de manier waarop het bewijs wordt gebruikt. ${ }^{12}$ Hierin wordt de aard van het bewijs, of het bewijs onafhankelijk van de wil bestaat, niet als toetsingscriterium genoemd, maar wel de aard en mate van dwang. Het nemo-teneturbeginsel is derhalve means based. Het beschermt tegen bepaalde wijze van verkrijging van bewijsmateriaal.

\subsection{Tussenconclusie}

De Nederlandse wetgever hangt in de memories van toelichting bij Boeken 1 en 2 een material based uitwerking van het beginsel aan. ${ }^{13}$ Volgens de wetgever beschermt het nemo-teneturbeginsel alleen tegen de gedwongen verkrijging van bepaalde bewijsmiddelen: 'Wat niet door het nemo-teneturbeginsel beschermd wordt, is materiaal dat onafhankelijk van de wil van de verdachte bestaat. ${ }^{14}$ Het nemo-teneturbeginsel zoals dat naar voren komt in de rechtspraak van het EHRM is echter means based. Het beginsel beschermt de verdachte tegen ongeoorloofde dwang, ongeacht welk soort bewijsmiddel de overheid wil vergaren. Dit blijkt uit de bewoordingen die het EHRM gebruikt bij de algemene beschrijving van het beginsel, uit verschillende arresten waarin de verkrijging en het gebruik van zowel materiaal dat afhankelijk van de wil bestaat als materiaal dat onafhankelijk van de wil bestaat artikel 6 EVRM schendt, en uit de drie toetsingscriteria die het Hof uiteenzet.

\section{Het nemo-teneturbeginsel in de conceptwetsvoorstellen}

De vraag is of de interpretatie van de EHRM-jurisprudentie door de wetgever van het nemo-teneturbeginsel problematisch is, in de zin dat de Nederlandse wetgever opsporingsmethoden introduceert of toestaat die de Straatsburgse toets niet kunnen doorstaan. Om dat te beoordelen, wordt in de onderhavige paragraaf bekeken welke bepalingen in de conceptwetsvoorstellen van Boek 1 en 2 zijn opgenomen die de verdachte verplichten aan de bewijsgaring mee te werken. Ik beperk mij tot die twee Boeken omdat het nemo-teneturbeginsel voornamelijk van belang is bij de begrenzing van tegen de verdachte gerichte dwang om bewijs in de opsporingsfase over te dragen of te vergaren.
12. EHRM 29 juni 2007, ECLI:CE:ECHR:2007:0629JUD001580902 par. 55 (O'Halloran \& Francis t. het Verenigd Koninkrijk).

13. Overigens wordt deze zichtwijze ook toegepast in Boek 4. Zie art. 4.3.2.5 lid 2 dat enkel voor verklaringen verkregen door een meewerkingsverplichting een bewijsverbod bevat. Zie ook Memorie van Toelichting: Vaststellingswet Boek 4 van het nieuwe Wetboek van Strafvordering (Berechting), p. 73-74.

14. Memorie van Toelichting: Vaststellingswet Boek 2 van het nieuwe Wetboek van Strafvordering (Het opsporingsonderzoek), p. 73-74. 
3.1. Het nemo-teneturbeginsel en de nieuwe bepalingen betreffende stem- en handschriftidentificatie

Artikel 2.6.5.5.1 bevat nieuwe mogelijkheden om onderzoek ten aanzien van fysieke ${ }^{15}$ eigenschappen uit te voeren. Daaronder vallen de verplichting voor de verdachte om mee te werken aan een handschriftvergelijkend onderzoek waarvoor hij een tekst moet schrijven, en het uitspreken van een tekst ten behoeve van een stemvergelijkend onderzoek of confrontatie. ${ }^{16}$ De vraag is of deze onderzoeken in het licht van nemo-teneturbeginsel een geoorloofde verplichting op de verdachte leggen.

Zoals hierboven is beargumenteerd, stelt het EHRM de aard en mate van de dwang centraal bij de beoordeling van klachten over schending van het nemo-teneturbeginsel. Welke aard en mate van dwang geoorloofd is, hangt af van welk soort bewijs wordt verkregen: 'materiaal dat afhankelijk van de wil van de verdachte bestaat kan (binnen grenzen) worden afgedwongen, terwijl daarnaast de verkrijging van materiaal dat onafhankelijk van de wil bestaat (gezien de aard en mate van dwang en het gebruik dat ervan is gemaakt) juist in strijd kan komen met het nemo-teneturbeginsel.' ${ }^{17}$ Bepaalde, zeer geringe dwang is geoorloofd bij de verkrijging van materiaal dat afhankelijk van de wil bestaat, terwijl materiaal dat onafhankelijk van de wil bestaat pas ongeoorloofd wordt verkregen wanneer artikel $3 \mathrm{EVRM}^{18}$ is geschonden of (te) hoge straffen worden opgelegd voor nietmedewerking casu quo de niet-medewerking met een (te) hoge straf wordt bedreigd.

Om te bepalen of de verdachte verplicht kan worden medewerking te verlenen aan een handschriftanalyse en stemvergelijking dient (1) vast te worden gesteld welk soort bewijsmiddel met die bevoegdheden wordt verkregen, om vervolgens (2) grenzen aan de toepasbare dwang te stellen. De wetgever ziet beide - het stemgeluid en het handschrift - als onafhankelijk van de wil bestaande bewijsmiddelen. ${ }^{19}$ De Raad voor de rechtspraak is in zijn advies over de Boeken 1 en 2 kritisch op deze zienswijze, waarbij hij de nadruk legt op het belang tussen meewerken en dulden omdat de handschriftvergelijking en de stemanalyse een actieve handeling van de

15. Ik betwijfel overigens ten zeerste of het stemgeluid en het handschrift als fysieke eigenschap kunnen worden bestempeld. Het betreft hierbij namelijk geen (op dit moment) vaststaande eigenschappen, zoals lichaamslengte, haarkleur, DNA-profiel, bloedgroep, vingerafdruk et cetera. Het stemgeluid en het handschrift zijn (mede) afhankelijk van de situatie waaronder het geluid of het schrift wordt geproduceerd (emotie, stress, tijdsdruk) en de fysieke gesteldheid (verkoudheid).

16. Dat dit geen actueel probleem is, blijkt uit het feit dat Weintraub al in 1957 schreef over precies deze twee bevoegdheden in het licht van het nemo-teneturbeginsel: R.J. Weintraub, 'Voice Identification, Writing Exemplars and the Privilege against Self-Incrimination', Vanderbilt Law Review 1957,3, p. 485-512.

17. Vgl. E.J. Gritter, 'Het decryptiebevel aan de verdachte in het economisch strafrecht', TBS\&H 2017, 4, p. 192

18. Binnen het EHRM bestaat discussie of dit moet worden uitgebreid met schendingen van artikel 8 EVRM. Zie daarover: D.A.G. van Toor, annotatie: Europees Hof voor de Rechten van de Mens, 31 oktober 2017, nr. 22767/08 (Dragoș loan Rusu t. Roemenië), EHRC 2018, 1, nr. 13.

19. Memorie van Toelichting: Vaststellingswet Boek 2 van het nieuwe Wetboek van Strafvordering (Het opsporingsonderzoek), p. 73-74. verdachte vereisen (namelijk schrijven of spreken). ${ }^{20}$ In de rechtspraak van het EHRM is de activiteit van de verdachte echter geen zelfstandig criterium, maar bepaalt het mede welke aard en mate van dwang geoorloofd is: de gebruikte dwang is en blijf het centrale criterium.

Terug naar de vraag of het stemgeluid en het handschrift onafhankelijk van de wil bestaan of juist onder controle van de wil staan. Ik beargumenteer hieronder dat laatste, al besef ik dat naar deze vormen van identificatie juist onderzoek wordt gedaan omdat het stemgeluid en het handschrift een bepaalde constantheid bevatten waarmee herkenning mogelijk is. Die constantheid duidt erop dat de stem en het handschrift een duidelijk patroon vertonen dat onafhankelijk is van de situatie. Die constantheid is echter niet absoluut: stemverdraaiingen zijn mogelijk, het stemgeluid is onder andere afhankelijk van (zelf opgeroepen) emotie en het stemgeluid van anderen kan (door sommige zelfs uitstekend en voor lange duur) worden geïmiteerd. Dat die (on)constantheid een probleem vormt bij stemidentificaties blijkt ook uit het feit dat herkenningen van personen enkel met de stem 'niet kan bogen op een indrukwekkende staat van dienst. ${ }^{21}$ Dit geldt mutatis mutandis voor de handschriftanalyse. Mensen kunnen bewust in verschillende handschriften schrijven, handschriften zijn afhankelijk van hoe lang en hoe snel wordt geschreven, ${ }^{22}$ en handschriften veranderen gedurende het leven. ${ }^{23}$ Het handschrift en de stem zijn geen vaststaande eigenschappen, zoals de inhoud van een document en het DNA van een persoon dit wel zijn.

In enige mate bestaat zowel het stemgeluid als het handschrift dus afhankelijk van de wil van de verdachte. Ik zie met betrekking tot het nemo-teneturbeginsel geen verschil tussen het uitspreken of opschrijven van een wachtwoord om daarmee vervolgens bestanden te ontsleutelen, te vergelijken en/of analyseren, en het uitspreken of opschrijven van een tekst om een persoon te identificeren. Het eerste - het decryptiebevel - is vanwege potentiële schending van het nemo-teneturbeginsel, als de ontsleutelde bestanden als bewijs zouden worden gebruikt, uit de Wet computercriminaliteit III

20. Deze zienswijze wordt vaker in de literatuur gebruikt, waarbij dan niet de nadruk wordt gelegd op de verkrijgingswijze vanuit overheidsperspectief - welke aard en mate van dwang mogen zij toepassen? - maar het perspectief van de verdachte - welke soort handeling mag van hem worden afgedwongen? Zie bijv.: B-J. Koops, Het decryptiebevel en het nemo-teneturbeginsel: Nopen ontwikkelingen sinds 2000 tot invoering van een ontsleutelplicht voor verdachten?, Den Haag: WODC 2012, p. 14, 138, 168; Commissie modernisering opsporingsonderzoek in het digitale tijdperk, Regulering van opsporingsbevoegdheden in een digitale omgeving, s.l. 2018, p. 105.

21. A.P.A. Broeders, 'Het herkennen van stemmen', in: P.J. van Koppen, J.W. de Keijser, R. Horselenberg \& M. Jelicic (red.), Routes van het Recht. Over de rechtspsychologie, Den Haag: Boom juridisch 2017, p. 379. Zie voor een vergelijkbare conclusie over de handschriftanalyse: J. Wang, 'A Comparison of the Identifying Features of Imitated Handwriting and Elderly Handwriting', J Forensic Sci Med 2017, 3, p. 38-41.

22. ledere docent herkent hoogstwaarschijnlijk de situatie dat het handschrift van studenten op het einde van het tentamen is veranderd (en meestal niet ten goede komt aan de leesbaarheid).

23. J. Wang, 'A Comparison of the Identifying Features of Imitated Handwriting and Elderly Handwriting', J Forensic Sci Med 2017, 3, p. 38-41. 
geschrapt. Hetzelfde zou moeten gebeuren met de stemvergelijking en de handschriftanalyse. Doordat de stem en het handschrift afhankelijk van de wil bestaan, kan slechts zeer minimale dwang worden toegepast: dwang die te vergelijken is met dwang die ter verkrijging van een verklaring mag worden toegepast. (Overigens kunnen beide bevoegdheden niet fysiek worden afgedwongen, anders dan het afnemen van lichaamsmateriaal, een fouillering of een inbeslagname.) Daarnaast is ook belangrijk dat de dwang de betrouwbaarheid van de resultaten kan aantasten. Juist een stressvolle situatie kan invloed hebben op de stem en het handschrift waardoor het te verkrijgen vergelijkingsmateriaal onbetrouwbaar is. Om te verzekeren dat betrouwbaar en voldoende vergelijkingsmateriaal wordt verkregen, lijkt het beter om materiaal dat al bestaat - en dat dus niet onder controle van de wil van de verdachte is - in beslag te nemen of te verzamelen. Mijn advies is het handhaven van de huidige situatie waarin deze vormen van analyse niet wettelijk zijn geregeld, en voor de vergelijking gebruik wordt gemakt van met toestemming van de verdachte verkregen of opgesteld materiaal of materiaal dat door middel van een andere bevoegdheid (zoals de inbeslagname van goederen ter waarheidsvinding) is verkregen. $^{24}$

\section{Conclusie}

De wetgever doet er goed aan de EHRM-jurisprudentie en literatuur over het nemo-teneturbeginsel nog eens te raadplegen. Zijn uiteenzetting over de functie van het nemo-teneturbeginsel is selectief, zijn visie (material based) is theoretisch onlogisch en strookt niet met de jurisprudentie, en ook het concrete beschermingsbereik is onjuist. Mede hierdoor heeft de wetgever beargumenteerd dat de toepassing van een stemvergelijking en handschriftanalyse waaraan de verdachte gedwongen moet meewerken geen schending van het nemo-teneturbeginsel oplevert. Ik zie dit evenwel anders: aangezien de stem en het handschrift afhankelijk van de wil bestaan, is enkel dezelfde aard en mate van dwang geoorloofd die tijdens een verhoor is toegestaan. De verdachte mag niet fysiek worden gedwongen te schrijven of te spreken, en op de niet-medewerking mag geen straf worden gesteld. De enige mogelijk om geoorloofd fysieke dwang toe te passen of een straf als stok achter de deur te gebruiken, is de verplichting om het uit de bevoegdheden verkregen bewijsmateriaal uit te sluiten (vgl. de in Van Weerelt ontwikkelde waarborg van de Hoge Raad). ${ }^{25}$ Mocht het doel van de bevoegdheden zijn

24. Zie Rb. Limburg 5 december 2016, ECLI:NL:RBLIM:2016:11632 voor een situatie waarin deze methoden - eerst een vrijwillige medewerking, of eventueel een vergelijking met al bestaand materiaal - als alternatieve methoden in de huidige strafvordering worden gebruikt.

25. De Hoge Raad oordeelt dat van een belastingplichtige op grond van artikel 47 AWR afgifte van wilsafhankelijk materiaal kan worden verlangd met het oog op een juiste belastingheffing, met als waarborg dat deze informatie niet ook voor fiscale beboeting of strafvervolging wordt gebruikt. HR 12 juli 2013, ECLI:NL:HR:2013:BZ3640, r.o. 3.9; EHRM 16 dat het materiaal ook als bewijs wordt gebruikt, dan doet de wetgever er goed aan (i) de bevoegdheden alleen met toestemming van de verdachte uit te voeren of; (ii) op een andere manier vergelijkingsmateriaal te vergaren. juni 2015, appl. no. 784/14, par. 66 (Van Weerelt t. Nederland) (beslissing). 